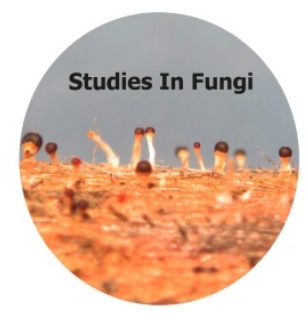

Studies in Fungi 4(1): 216-222 (2019) www.studiesinfungi.org ISSN 2465-4973

\title{
Article
}

Doi 10.5943/sif/4/1/23

\section{Paracremonium moubasheri, a new species from an alkaline sediment of Lake Hamra in Wadi-El-Natron, Egypt with a key to the accepted species}

\author{
Al-Bedak $\mathrm{OA}^{1^{*}}$, Ismail MA ${ }^{1,2}$ and Mohamed $\mathrm{RA}^{2}$ \\ ${ }^{1}$ Assiut University Mycological Centre (AUMC), Assiut University, Assiut, Egypt \\ ${ }^{2}$ Department of Botany and Microbiology, Faculty of Science, Assiut University, Assiut, Egypt
}

Al-Bedak OA, Ismail MA, Mohamed RA 2019 - Paracremonium moubasheri, a new species from an alkaline sediment of Lake Hamra in Wadi-El-Natron, Egypt with a key to the accepted species. Studies in Fungi 4(1), 216-222, Doi 10.5943/sif/4/1/23

\begin{abstract}
During surveys of extremophilic fungi in hypersaline, alkaline lakes of Wadi-El-Natron, Egypt, an interesting fungus was recovered from a mud sample collected from Lake Hamra in Wadi-El-Natron, Egypt. Maximum likelihood analysis of Internal Transcribed Spacer (ITS) gene along with morphological comparisons of related taxa revealed a novel taxon, Paracremonium moubasheri which is described and illustrated in the current study. Paracremonium moubasheri can be distinguished from the known species of the genus by its large conidia, in addition to the presence of chlamydospores.
\end{abstract}

Key words - Acremonium-like - Hypersaline - Hypocreales - new taxon - Phylogeny

\section{Introduction}

Paracremonium is acremonium-like genus related to order Hypocreales which includes approximately 2700 species belonging to 240 genera (Crous et al. 2014). The genus Paracremonium was introduced by (Lombard et al. 2015), and since this date 5 species appertaining to that genus were described namely P. binnewijzendii Houbraken, van der Klij \& L. Lombard, P. contagium L. Lombard \& Crous, P. inflatum L. Lombard \& Crous, P. pembeum S.C. Lynch \& Eskalen, and P. variiforme Z.F. Zhang, F. Liu \& L. Cai. The genus Paracremonium is characterized by hyaline, septate, branched hyphae which sometimes forming sterile coils from which conidiophores arising. These morphological characters can distinguish the genus Paracremonium from other acremonium-like genera. Some species of Paracremonium are associated with human infections as $P$. inflatum which isolated from a granulomatous lesion of a male in India and $P$. contagium from a subcutaneous lesion of a male in Canada (Lombard et al. 2015). However some others as $P$. binnewijzendii was isolated from stream embankments in the Netherlands (Crous et al. 2017), P. pembeum from Acer negundo L., Persea americana Mill., Platanus racemosa Nutt., Ricinus communis L. trees and heads of Euwallacea sp. in California, USA (Lynch et al. 2016), and P. variiforme from water sample of karst cave in China (Zhang et al. 2017). Reports of fungi from extremely hypersaline environments are very limited compared with other habitats like soil. However, lack of representation in the literature may reflect the little effort that has been payed to recover them. Therefore, the present study was conducted for 
identification of new taxa in such extreme habitats like saline lakes of Wadi-El-Natron in Egypt.

\section{Materials and methods}

\section{Sampling and strain isolation}

Mud samples were collected from Lake Hamra. The dilution plate technique (Harris \& Sommers 1968) was employed for isolation of the fungi from mud samples using $1 \%$ glucose-Cz medium (Ismail et al. 2017). After incubation at $25{ }^{\circ} \mathrm{C}$ for 15 days, the developed colonies were purified and maintained on $\mathrm{Cz}$ slants at $4{ }^{\circ} \mathrm{C}$ for further investigation. It was preserved and deposited as pure culture in the culture collection of the Assiut University Mycological Centre as AUMC 11030 and the sequence of ITS region was uploaded to GenBank as KX384655.

\section{Morphological studies}

Cultural morphological characteristics and growth rates were studied on malt extract agar (MEA, (Samson 2010), Czapek's agar (CZ, (Raper \& Fennell 1965), and potato dextrose agar (PDA, (Smith \& Onions 1994) at $30^{\circ} \mathrm{C}$ in addition to on $\mathrm{Cz}$ at $5{ }^{\circ} \mathrm{C}, 25^{\circ} \mathrm{C}$ and $37^{\circ} \mathrm{C}$. Inoculations were made from spore suspension prepared in a $0.2 \%$ agar and $0.05 \%$ Tween 80 solution (Samson et al. 2014). Plates were inoculated in three-point pattern using a micropipette and inoculum size of $1 \mu \mathrm{l}$ per spot. Unwrapped cultures were incubated in the dark reverse side. Microscopic features on $\mathrm{Cz}$ were examined in lacto-phenol cotton blue.

\section{Molecular studies}

\section{DNA extraction}

Prior to DNA extraction, small piece of fungal mycelia of Paracremonium moubasheri cultured on $\mathrm{Cz}$ agar plates at $30{ }^{\circ} \mathrm{C}$ for 7 days were collected and transferred to $2 \mathrm{ml}$-Eppendorf tube. DNA extraction was performed following the method of (Moubasher et al. 2019).

\section{PCR amplification}

The PCR reaction was performed using SolGent EF-Taq. The universal primers ITS1 and ITS4 (White et al. 1990) were used for DNA amplification. In the PCR tubes $1 \mu$ l of DNA template, $1 \mu \mathrm{l} 2.5 \mathrm{mM}$ dNTP mix, 0.2 unit of Taq polymerase, $5 \mu \mathrm{l}$ of $10 \mathrm{x}$ complete buffer and $40 \mu \mathrm{l}$ of sterile ddH2O, 10 pmol of ITS1 (5' TCC GTA GGT GAA CCT TGC GG 3’) and ITS4 (5' TCC TCC GCT TAT TGA TAT GC $3^{\prime}$ ) were added. Amplification was conducted using the following PCR reaction conditions: one round of amplification consisting of denaturation at $95{ }^{\circ} \mathrm{C}$ for $15 \mathrm{~min}$ followed by 30 cycles of denaturation at $95{ }^{\circ} \mathrm{C}$ for $20 \mathrm{sec}$, annealing at $50{ }^{\circ} \mathrm{C}$ for $40 \mathrm{sec}$ and extension at $72{ }^{\circ} \mathrm{C}$ for $1 \mathrm{~min}$, with a final extension step of $72 \mathrm{C}$ for $5 \mathrm{~min}$. The PCR products were then purified with the SolGent PCR Purification Kit-Ultra (SolGent, Daejeon, South Korea) prior to sequencing. $1 \%$ agarose gel was used for confirmation of the purified PCR products by electrophoreses. Then these bands were eluted and sequenced in the forward and reverse directions.

\section{Phylogenetic analysis}

Sequence data of all published Paracremonium species including sequences of the available type materials were downloaded from GenBank. The phylogenetic analysis was carried out using the Maximum Likelihood method and General Time Reversible model (Nei \& Kumar 2000). The bootstrap consensus tree inferred from 100 replicates was taken to represent the phylogenetic analysis of the taxa analyzed (Felsenstein 1985). Branches corresponding to partitions reproduced in less than $50 \%$ bootstrap replicates are collapsed. The percentage of replicate trees in which the associated taxa clustered together in the bootstrap test are shown next to the branches (Felsenstein 1985). Initial tree(s) for the heuristic search were obtained automatically by applying NeighborJoin and BioNJ algorithms to a matrix of pairwise distances estimated using the Maximum Composite Likelihood (MCL) approach, and then selecting the topology with superior log 
likelihood value. A discrete Gamma distribution was used to model evolutionary rate differences among sites $(5$ categories $(+G$, parameter $=1.4098)$ ). The rate variation model allowed for some sites to be evolutionarily invariable ([+I], 25.53\% sites). This analysis involved 13 nucleotide sequences. All positions with less than $95 \%$ site coverage were eliminated, i.e., fewer than $5 \%$ alignment gaps, missing data, and ambiguous bases were allowed at any position (partial deletion option). There was a total of 380 positions in the final dataset. Evolutionary analyses were conducted in MEGA X (Kumar et al. 2018)

\section{Results}

The new taxon was isolated from mud sample characterized by alkaline $\mathrm{pH}$ value of 9.74, high total dissolved solids (TDS) of $12.6 \%$, high sodium (185.7 g/kg dry mud) and total chlorides (59.3 g/kg dry mud) contents (Ismail et al. 2017) revealing the extremophilic nature of the new species since it was isolated from a typical hypersaline, alkaline habitat.

\section{Phylogenetic analysis}

The ITS dataset comprised 13 sequences, of which 10 are Paracremonium and 3 sequences of Cosmospora (Fig. 1). The ML analysis of ITS data set yielded a best scoring RAxML tree (Fig. 1). The phylogenetic analysis revealed that $P$. moubasheri is grouped with other species of Paracremonium but in a single branch in the phylogenetic tree indicating that this is a new species. It has a homology percentage ranged from $92.68 \%$ with $P$. contagium to $96.95 \%$ with $P$. inflatum.

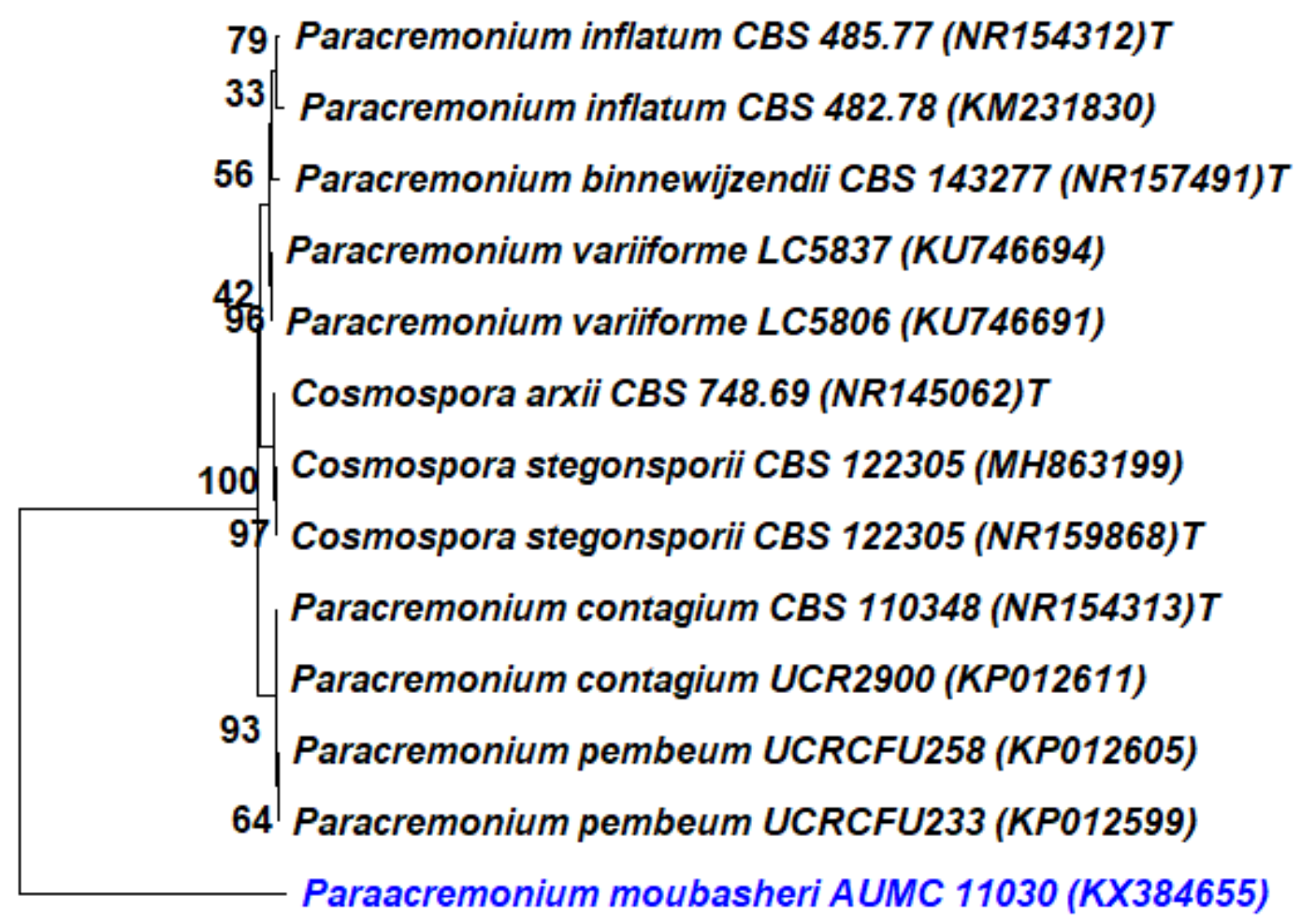

\subsection{0}

Fig. 1 - Maximum Likelihood tree of Paracremonium moubasheri (AUMC 11030) and other Paracremonium species based on the data of the ITS gene sequences (GenBank accession numbers in parentheses; type species are signed with $(\mathrm{T})$; sequence of the new species in blue). 
Paracremonium moubasheri Al-Bedak OA \& Ismail MA, sp. nov.

Fig. 3

GenBank number: KX384655; Mycobank number: MB831989;

Facesoffungi number: FoF 06585

Etymology - Named after Moubasher AH, Founder of the Assiut University Mycological Centre (AUMC), Assiut University, Assiut Governorate, Egypt.

Typification: EGYPT. Wadi-El-Natron: Lake Hamra, from alkaline mud sample, 2 Feb 2012, Osama A. Al-Bedak (holotype AUMC 11030).

Cultural characteristics - Colonies on $\mathrm{Cz}$ agar attaining a diameter of $40-50 \mathrm{~mm}$ after 14 days at $30{ }^{\circ} \mathrm{C}$, greyish-orange (5B-3), raised in the center with aerial mycelial tufts; margin entire, flat, paler than the colony center, narrow; reverse clay (5D-5). On PDA at $30{ }^{\circ} \mathrm{C}$ colonies reaching $35-$ $42 \mathrm{~mm}$ in diameter after 14 days, orange white (5B-2), flat to slightly raised in the center, margin entire, flat, wide; reverse champagne (4B-4). On MEA colonies attaining $43-50 \mathrm{~mm}$ in diameter after 14 days at $30{ }^{\circ} \mathrm{C}$, brownish-orange (5C-3), flat to slightly raised colony center, margin entire, flat, paler than the colony center; reverse yellowish brown (5D-8). On $\mathrm{Cz}$ at $5{ }^{\circ} \mathrm{C}$ after 14 days colonies restricted, attaining 6-8 mm diameter. Colonies on $\mathrm{Cz}$ after 14 days attaining a diameter of $35 \mathrm{~mm}$ at $25^{\circ} \mathrm{C}$ and a diameter of $35-38 \mathrm{~mm}$ at $37^{\circ} \mathrm{C}$, greyish-orange (5B-3), raised in the center with aerial mycelial tufts; margin entire, flat, paler than the colony center; reverse nougat (5D-3) (Fig. 2).

Asexual morph: Vegetative hyphae 1-2 $\mu \mathrm{m}$ width, hyaline, smooth- and thin-walled, septate, branched. Sterile coiled hyphae absent. Conidiophores consisting of single, hyaline, smoothwalled, erect, tapered, unbranched or rarely branched, 0-1 septate phialides, commonly (15-) 30-50 $(-100) \times 2-3 \mu \mathrm{m}(\mathrm{n}=50)$ or 2 phialides may be borne on a stipe arising from vegetative and aerial hyphae. Phialides 1-1.5 $\mu \mathrm{m}$ width, hyaline, smooth, elongate-ampulliform, tapering towards apex. Conidia (7-) 10-12 (-16) × 2-3 $\mu \mathrm{m}(\mathrm{n}=100)$, hyaline, smooth-walled, aseptate, fusiform, straight to slightly curved, commonly formed in slimy heads. Chlamydospores abundant, 10-17 × 7-15 $\mu \mathrm{m}$ ( $n=100)$, globose to subglobose. Sexual morph: Ascomata not observed (Fig. 3).

Key to known species of Paracremonium

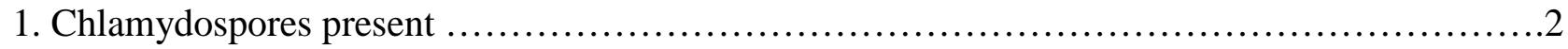

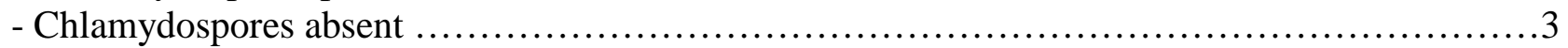

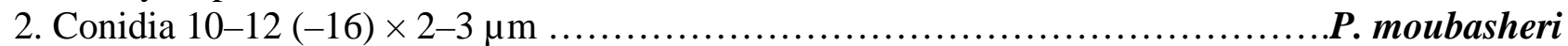

- Conidia 4.5-7.0 $\mu \mathrm{m}$............................................................. pembeum

3. Conidiophores bearing whorls of 2-4 phialides, conidia 9-14.5 $\times 4-6 \mu \mathrm{m}$...........P. variiforme

- Conidiophores simple ................................................................

4. Sterile coils from which conidiophores radiating outwards present, conidia 5-6 6 1-2 $\mu \mathrm{m}$

................................................................................. inflatum

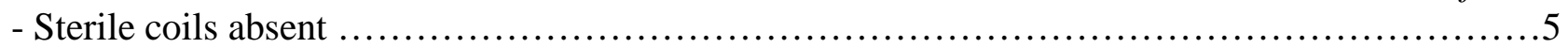

5. Conidia 7-11 (-13) × (1.5-)2.5-3.5(-4.5) $\mu \mathrm{m}$................................ binnewijzendii

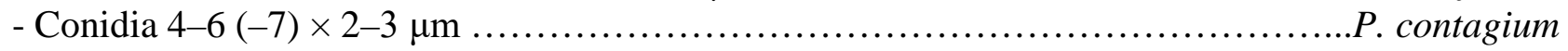

\section{Discussion}

The genus Paracremonium was recently established for different fungal strains previously treated as Acremonium recifei (Lombard et al. 2015). According to the available literatures, five species were described in the genus Paracremonium namely $P$. binnewijzendii, $P$. contagium, $P$. inflatum, $P$. pembeum and $P$. variiforme. Paracremonium binnewijzendii was isolated from stream embankments in The Netherlands (Crous et al. 2017), while P. contagium (Canada) and P. inflatum (India and Colombia) are associated with human infections (Lombard et al. 2015), P. pembeum with trees of Acer negundo, Persea americana, Platanus racemose and Ricinus communis in addition to heads of Euwallacea sp. in California, USA (Lynch et al. 2016) and P. variiforme from water sample of karst cave in China (Zhang et al. 2017), in addition to the new species $P$. 
moubasheri (described here) which was isolated from an alkaline sediment from Lake Hamra in Wadi-El-Natron, Egypt.

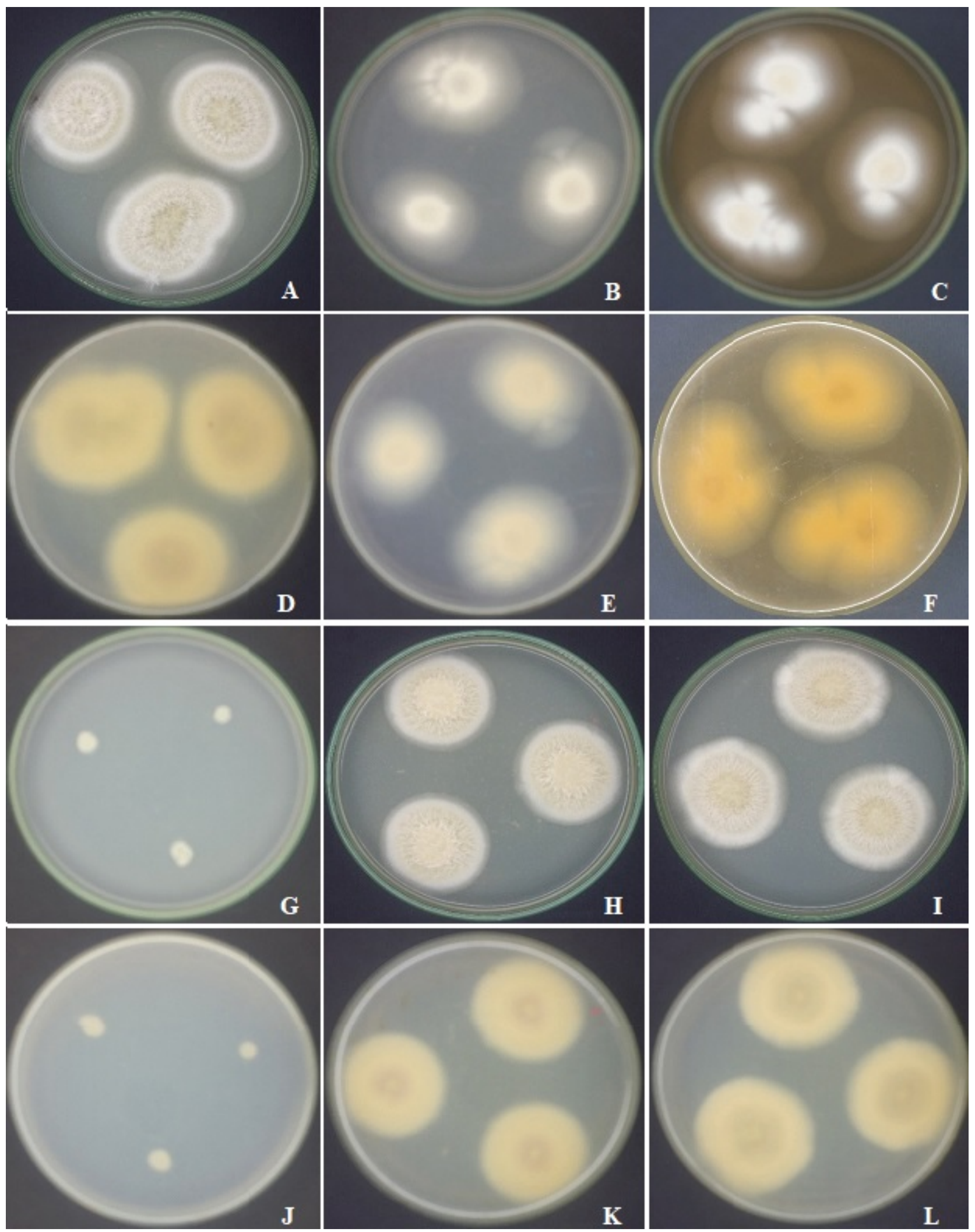

Fig. 2 - Paracremonium moubasheri (AUMC 11030). A-C colonies on Cz, PDA and MEA after 14 days at $30^{\circ} \mathrm{C}$. D-F reverse on Cz, PDA and MEA. G-I colonies on $\mathrm{Cz}$ after 14 days at $5{ }^{\circ} \mathrm{C}$ $25^{\circ} \mathrm{C}$ and $37^{\circ} \mathrm{C}$. $\mathrm{J}-\mathrm{L}$ reverse on $\mathrm{Cz}$ at $5{ }^{\circ} \mathrm{C}, 25^{\circ} \mathrm{C}$ and $37^{\circ} \mathrm{C}$. 

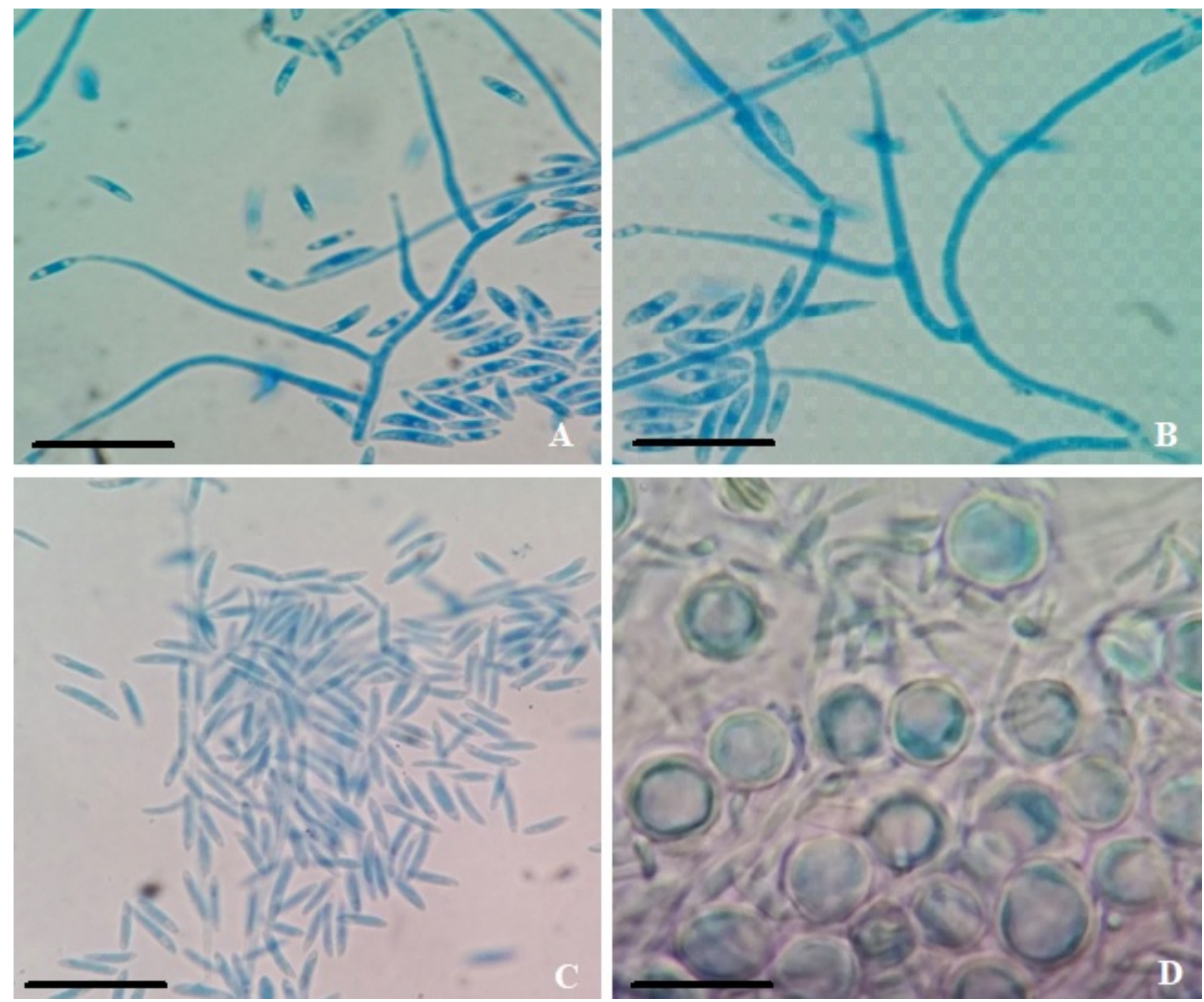

Fig. 3 - Paracremonium moubasheri (AUMC 11030). A unbranched conidiophores. B branched conidiophores. C fusiform, straight to slightly curved conidia. D globose to subglobose chlamydospores (Scale bar $=20 \mu \mathrm{m}$ ).

Based on megablast search using the ITS sequence of the new species, the closest matches in GenBank nucleotide database were $P$. inflatum CBS 485.77 [(GenBank NR154312 and KM231829; Identities 540/557 (96.95 \%), 2 gaps (0 \%)] with interspecific difference of 17 nucleotides, and P. binnewijzendii CBS 143277 [(GenBank NR157491; Identities 537/562 (95.55 \%), 7 gaps (1\%)] with interspecific difference of 25 nucleotides.

Paracremonium moubasheri can be distinguished from the other species in the genus by its large conidial size and presence of chlamydospores. The conidia of $P$. moubasheri are commonly 10-12 (-16) $\mu \mathrm{m}$ in length, and the conidia of the other species in the genus are usually less than 7 $\mu \mathrm{m}$ long except $P$. binnewijzendii and $P$. variiforme which have large conidia but no chlamydospores are absent. Paracremonium pembeum produces globose to ellipsoidal, hyaline, thick-walled chlamydospores but differs from the new species by its small conidia (4.5-7.0) $\mu \mathrm{m}$. $P$. moubasheri can be distinguished from Paracremonium inflatum by the absence of sterile coils from which conidiophores radiate and presence of chlamydospores which not produced in $P$. inflatum. Also, $P$. moubasheri can be distinguished from $P$. contagium by its large size conidia and the presence of chlamydospores. 


\section{Acknowledgement}

Professor Ahmed M. Moharram, the present Director of the AUMC is greatly appreciated and acknowledged for his kind reviewing the manuscript.

\section{References}

Crous P, Shivas R, Quaedvlieg Wv, Van der Bank M et al. 2014 - Fungal Planet description sheets: 214-280. Persoonia: Molecular Phylogeny and Evolution of Fungi 32, 184.

Crous PW, Wingfield MJ, Burgess T, Carnegie A et al. 2017 - Fungal Planet description sheets: 625-715. Persoonia: Molecular Phylogeny and Evolution of Fungi 39, 270.

Felsenstein J. 1985 - Confidence limits on phylogenies: an approach using the bootstrap. Evolution 39, 783-791.

Harris R, Sommers L. 1968 - Plate-dilution frequency technique for assay of microbial ecology. Appl. Environ. Microbiol. 16, 330-334.

Ismail MA, Moubasher AH, Mohamed RA, Al-Bedak OA. 2017 - Extremophilic fungi and chemical analysis of hypersaline, alkaline lakes of Wadi-El-Natrun, Egypt. International Journal of Technical Research and Science 1, 345-363.

Kumar S, Stecher G, Li M, Knyaz C, Tamura K. 2018 - MEGA X: molecular evolutionary genetics analysis across computing platforms. Molecular biology and evolution 35, 1547-1549.

Lombard L, Van der Merwe N, Groenewald J, Crous PW. 2015 - Generic concepts in Nectriaceae. Studies in Mycology 80, 189-245.

Lynch SC, Twizeyimana M, Mayorquin JS, Wang DH et al. 2016 - Identification, pathogenicity and abundance of Paracremonium pembeum sp. nov. and Graphium euwallaceae sp. nov.two newly discovered mycangial associates of the polyphagous shot hole borer (Euwallacea sp.) in California. Mycologia 108, 313-329.

Moubasher AH, Ismail MA, Al-Bedak OA, Mohamed RA. 2019 - Ramophialophora chlamydospora, a new species from an alkaline lake of Wadi-El-Natron, Egypt. Asian Journal of Mycology 2, 110-117.

Nei M, Kumar S. 2000 - Molecular evolution and phylogenetics. Oxford university press.

Raper KB, Fennell DI. 1965 - The genus Aspergillus.

Samson RA. 2010 - Food and indoor fungi. CBS-KNAW Fungal Biodiversity Centre.

Samson RA, Visagie CM, Houbraken J, Hong S-B et al. 2014 - Phylogeny, identification and nomenclature of the genus Aspergillus. Studies in mycology 78, 141-173.

Smith D, Onions AH. 1994 - The preservation and maintenance of living fungi. CAB international.

White TJ, Bruns T, Lee S, Taylor J. 1990 - Amplification and direct sequencing of fungal ribosomal RNA genes for phylogenetics. PCR protocols: a guide to methods and applications 18, 315-322.

Zhang Z, Liu F, Zhou X, Liu X, Liu S, Cai L. 2017 - Culturable mycobiota from Karst caves in China, with descriptions of 20 new species. Persoonia: Molecular Phylogeny and Evolution of Fungi 39, 1. 